\title{
医薬品情報における有用な書籍
}

大 津 史 ${ }^{1}$ 渡 邊 玲 ${ }^{2}$ 奥 田 潤 ${ }^{3}$

名城大学薬学部医薬情報センター

I .はじめに したい。

ソリブジン事件, 薬害エイズ……, 何度も繰り 返される薬害。この背景の 1 つには, 医療従事者 の情報というものに対する取り組みや考え方の甘 さがあったのではないだろうか。医療における情 報, なかであ医薬品に関する情報を医薬品情報と いう。我々は, 医薬品情報とは「医薬品に関わる 人間の行動において，その意志決定をするための 根拠」と定義している。医師が, 薬を選択する時, 患者が薬を服用する時, 常になんらかの意志決定 がなされているはずである。ここに, 正確で新し い適正な情報が提供されてこそ, 初めて正しい意 志決定をすることができる。その情報を供給する 重責, これこそ今, 社会が薬剤師という職能に求 めていることではないのかと考える。

名城大学薬学部医薬情報センターでは, この薬 剂師を育成, 援助すべく, 医薬品情報学教育, 薬 剂師からの質問への応需, 副作用情報の研究等を 行っている。その一環として, 医薬品情報の情報 源で特に有用な資料やメディアを紹介した「医薬 品情報の資料 370 選」という解説資料を作成して いる。今回は，その中から医薬品情報において特 に有用と考えられる書籍をピックアップして紹介

${ }^{1}$ Fumiko OHTSU: T468 名古屋市天白区八事山 150.

${ }^{2}$ Reiko WATANABE. ${ }^{3}$ Jun OKUDA.

（1996 年 9 月 30 日 受理）

\section{II． 医薬品情報において特に有用な書籍}

医薬品情報において, 最も基本となる情報源は, 医薬品に添付される製薬メーカー作成の「添付文 書」といわれるものである。しかし, 添付文書は, 基本情報であって, 決してすべての情報を網羅し たあのではなく，常に更新されるが，限界もある 資料であることを認識しておかなければならない。 そしてそれを補う情報源としての書籍, 雑誌, 二 次資料, オンライン検索やインターネットといっ たメディアについて熟知しておく必要がある。

ソリブジン事件以来, 薬と薬が影響を及ぼし合 う「相互作用」という言葉が市民権を得た感があ る。そこでまず, 具体的な相互作用の例について, どのような書籍にどのような記載があり, どのよ うな特徴があるか, 記載内容を比較しながら紹介 したい。

\section{1．相互作用情報に関する書籍}

「不整脈に使われるジソピラミド（リスモダ ン $\left.{ }^{\circledR}\right)$ と結核の薬リファンピシンの相互作用」を 例に挙げる。

まず, 基本情報源であるジソピラミドの添付文 書をみてみると, 残念ながら相互作用の項目自体 が存在しない（後述の注参照）。

では，日本の代表的な医薬品集をみてみよう。 


\begin{tabular}{|l|}
\hline 不整胍治寮剂 212 \\
\hline \begin{tabular}{|} 
ジソ゚ラミド \\
disopyramide (JP)
\end{tabular} \\
\hline
\end{tabular}

の維持原法は，できるだけ速やかに経口投与に切り換える ②禁忌 @(内服)高度の房室ブロック, 高度の洞房ブロックのある患者。 （注射)重篤な刺激伝道障害(高度の房室ブロック, 高度の洞房ブロ ック)のある患者 ()(内服)うっ血性心不全のある患者。(注射)重 第なうっ血性心不全のある患者 (緑内障，尿眝留傾向のある患者 B犆重投与 ( (内服)基礎心疾患(心筋梗塞，弁膜症，心筋症等)の ある患者。(注射)高度の心桩大のある患者 (b)(内服)刺激伝導障害 （房室ブロック，洞房ブロック，脚ブロック等)のある患者。(注射) 刺激伝尊障害(房室プロック，洞房ブロック)のある患者 @心房粗 動のある患者(房室内伝道を促進することがある) @重第な肝障害

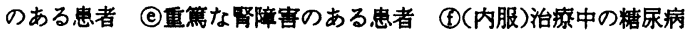
患者 (B)(内服)重症筋無力症の患者 (B)(内服)血清カリウム低下の ある患者 (1)(内服)高龄者 (1)(注射)うっ血性心不全の患者 (囚 (注射)心筋症, 心能炎の患者 ○副作用 @循環器:(普通郕)とき
に心室頻拍( Torsades de pointes を含む)，房室ブロック，その他 の徐脈が，また，まれに心房細動，心房粗動，心室細動，心室粗動， 失神, QT の延長等が現れることがあるので, 定期的に心電図検查 を行い，異常が認められた場合には，中止するなと適切な処置を行 う。また, まれに胸部圧迫感, 胸部不快感, 胸痛, 心胸比增大, 心 不全增強，血圧下降等が現れることがある。(徐放凨)ときに徐胍， また，まれに心室頻拍( Torsades de pointes を含む)，心房粗動， 房室フロック, 洞停止, QT 延長等が現れることがあるので定期的 に心電図検查を行い，異常が認められた場合には，中止するなと道 切な処置を行う。また，まれに動悸等が現れることがある。（注射） ときに心室稩動, 心室粗動, 心室類拍( Torsades de pointes を含 む), 心室性期外収縮, プロックを伴う発作性心房性頻拍, 房室フ ロック, 心房停止, 洞停止, 心停止, PQ 延長, QRS 延長, 血圧低 下が現れることがあるので，钼察を十分に行い，このような症状が 現れた場合には直ちに中止し, 適切な処置を行う (b)ショック(注 射):まれにショックを起こすことがあるので，観察を十分に行い， 異常が認められた場合には中止し，適切な処置を行う @低血糖 (内服)：まれに低血糖が現れることがあるので, 低血糖症状が現れ た場合には中止するなと適切な処直を行う @血液(普通郕)：まれ

\section{図 1．医療薬日本医薬品集（一部抜粋）}

図 1 は日本の添付文書集ともいうべき「医療薬日 本医薬品集 1995 日本医薬情報センター, 薬業 時報社」のジソピラミドの使用上の注意部分の抜 粋である。医療薬日本医薬品集は，厚生省薬務局 の援助と各メーカーの協力を得て，常時国内で使 用されている医薬品について，最新の添付文書の 内容を収録，整理し，他の資料からの情報む加え て編集したものである。医薬品の一般名，商品名 から検索することができるほか，新薬や製薬企業 住所録等の種々の付録がついている。この 10 月 には 1996 年 10 月版が CD-ROM 版と同時に出版 される。CD-ROM 版は, 年 4 回のデータ更新(有 料)があり, 保険薬事典, 識別ハンドブック，長 期投与医薬品便覧の内容をも含むため, 応用範囲 も広い。今回のバージョンからは，各病院の採用

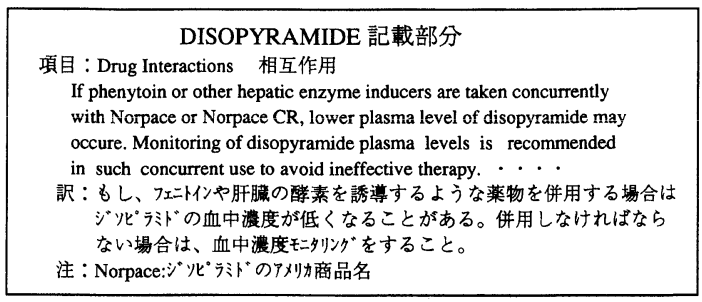

図 2.PDR (一部拔粋)
の有無やメモを記入できる機能が搭載されている。 では，記載内容に目を向けてみよう。本来なら 『慎重投与』と『副作用』という項目の間（図 1 , 矢印）に相互作用の項目があるのが一般的である が，ジソピラミドにはない。この書籍の基本情報 源は添付文書であるため，当然のことである。

さて，添付文書にも医療薬日本医薬品集にも相 互作用の記載がない。はたして本当にこの両者の 薬剤に相互作用は存在しないのであろうか。

図 2 は, アメリカの添付文書集 PDR 96 のジソ ピラミドの相互作用部分の抜粋である。「PDR :

Physicians' Desk Reference, Medical Economic Company Inc」は，アメリカの主要医薬品の添付 文書集で，一般名之商品名索引，メ一カ一別商品 名索引, 薬効別索引を持っている。本文はメーカー 別に製品の解説がされており，カラーの商品実物 大写真む収載されている。別冊として相互作用と 副作用からの索引と適応疾患別索引がある。さて, 相互作用の記載はどうであろうか。リファンピシ ンの名前こそあがっていないが，肝臓の酵素を誘 導する薬剤には注意が必要であり, 血中濃度モ二 タリングが必要である旨が記載されている。「肝 臓の酵素を誘導する薬剤? 」, リファンピシンは 


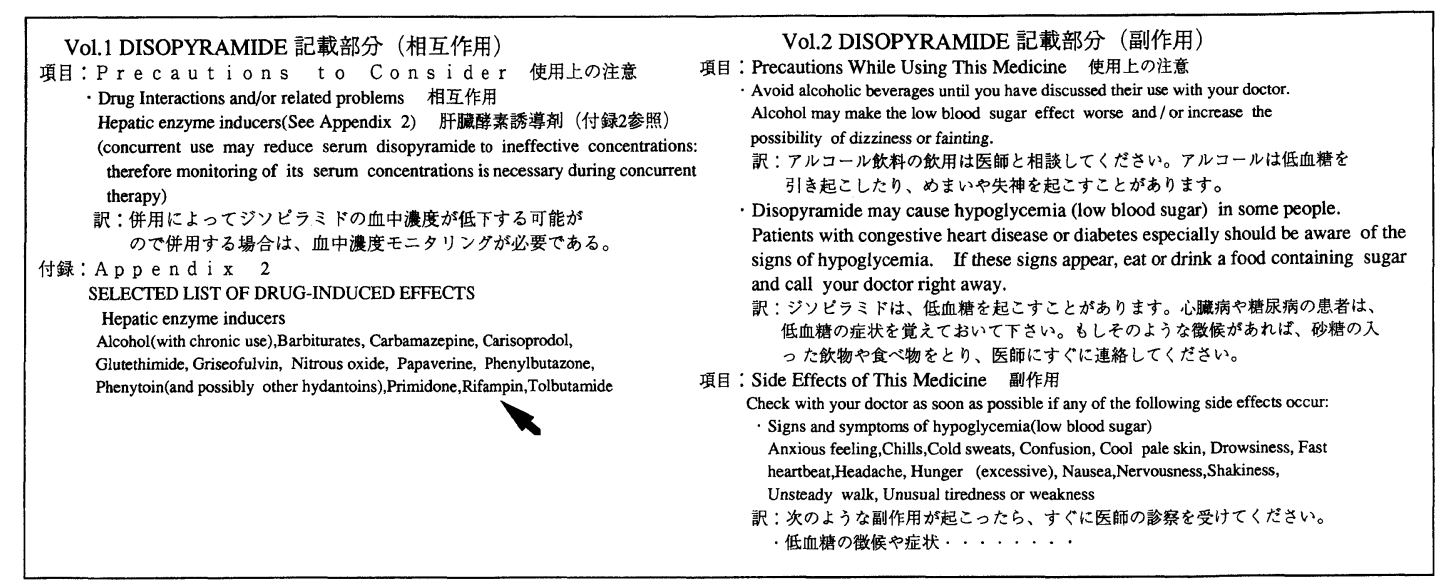

図 3.USP-DI 96 (一部抜粋)

関係しないのだろうか。

図 3 は, USP-DI 96 の一部抜粋である。「USPDI : USP Dispensing Information, USP Convention Inc」は, アメリカ薬局方 (USP : United States Pharmacopoeia)に収載されている医薬品 の臨床応用についての解説書で, Vol.1 : Drug Information for the Health Care Professional, Vol.2:Advice for the Patient, Vol.3:Approved Drug Products and Legal Requirements の 3 分 冊となっている。

Vol.1 は医師, 薬剤師等, プロ向けの医薬品情 報集で, 各医薬品もしくは薬効ごとにその薬剤の 物性や体内動態値, 薬理作用, 効能 - 効果, 注意 事項, 副作用, 患者への助言事項, 投与量などが 解説されている。

Vol.2 は患者への服薬指導解説書ともいうべき あので, 薬の使い方, 注意事項などを簡単な表現 で一般の人にあわかりやすく解説してある。

Vol.3 は処方薬のリスト等である。この書籍の 編集には, 医療従事者の各団体のみならず, 患者 の代表としての消費者団体が参加しており，国民 のコンセンサスを得た情報源として世界的に評価 が高い。

さて, 相互作用部分の記載であるが, 図 3 左が,
Vol.1 の相互作用部分の抜粋である。肝蔵酵素誘 導剤に注意すべき点の記載と, 付録として, 肝臓 酵素誘導剤のリストが添付されており, リファン ピシン（アメリカ名 Rifampin）の名前がはっき りと(矢印)記載されている。

図 3 右は, Vol.2つまり患者への服薬指導解説 書の副作用 (低血糖) の記載部分である。この Vol.2 の大きな特徴は, この副作用部分の記載方 法である。ジソピラミドはまれに低血糖という副 作用を引き起こすことがあるが，患者への情報提 供を考えた場合,「低血糖が起こるかもしれませ ん。」では, 患者はなんの意志決定むすることが できない。自分自身の身に起こっていることが低 血糖症状なのかぞうか, その判断ができる情報で なければ意味がない。Vol.2では, 低血糖の諸症 状を患者が感知し, 理解できると思われる表現で 記載して, その対処方法（すぐに砂糖の入った食 べ物をとるなどの対処）あ記載されている。

図 4 は, 相互作用専門の書籍の抜粋である。左 には, 日本の相互作用専門の書籍として,「医薬 品相互作用ハンドブック, 厚生省薬務局企画課 監, 薬業時報社, 1992」を挙げた。薬物療法上重 要な相互作用 242 の組み合わせについての作用, 処置等の解説のほか, 臨床医からのコメントおよ 
医薬品相互作用ハンドブック

\begin{tabular}{|c|c|c|}
\hline \multicolumn{3}{|c|}{ ジソピラミド リファンピシン } \\
\hline \multirow{2}{*}{ 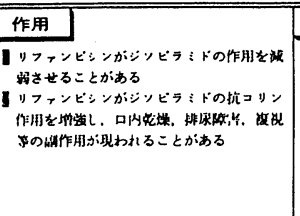 } & \multicolumn{2}{|c|}{ 機序 } \\
\hline & \multicolumn{2}{|c|}{ 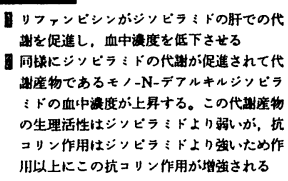 } \\
\hline \multirow{2}{*}{\multicolumn{3}{|c|}{ 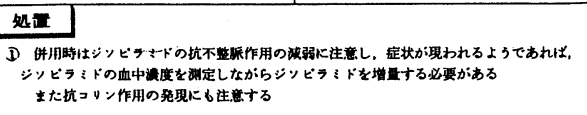 }} \\
\hline & & \\
\hline \multirow{3}{*}{\multicolumn{2}{|c|}{ 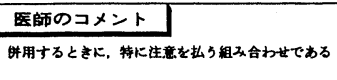 }} & 各程数值 \\
\hline & & 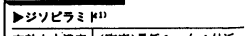 \\
\hline & & 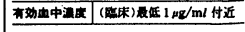 \\
\hline 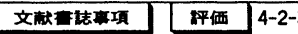 & & \\
\hline 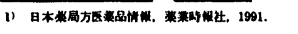 & & \\
\hline
\end{tabular}

\section{Drug Interactions Facts}

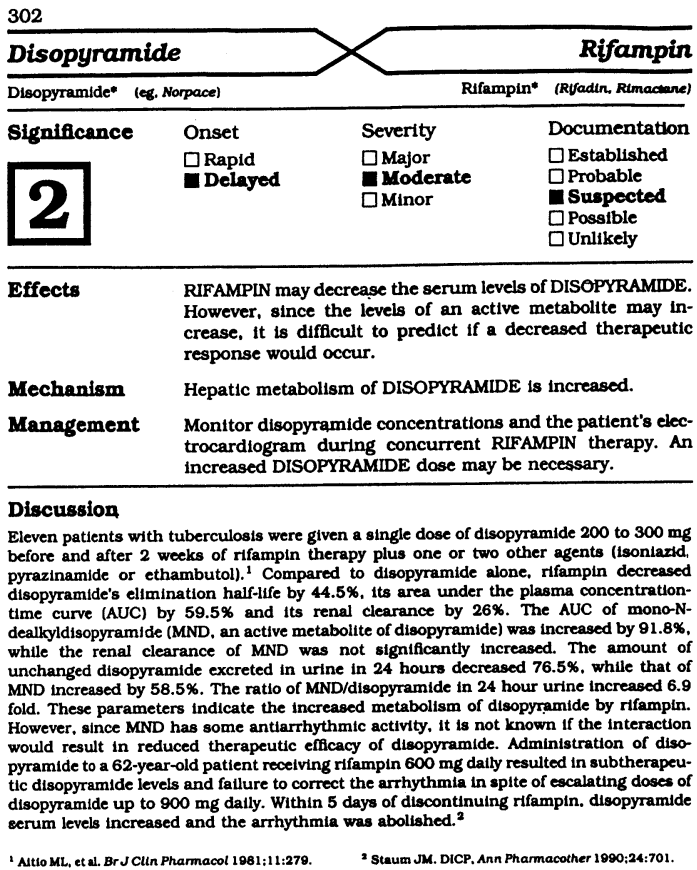

- Asterisk tndicates drugs cited in interaction reports.

図 4. 相互作用專門書籍（一部抜粋）

び各主要文献における評価をコンパクトにまとめ た実用書である。相互作用の臨床的意義と対応, 相互作用発症のメカニズムにも言及されている。 この本は, アメリカの相互作用の有用な 3 冊の書 籍を元に書かれたものであるが，その元本の 1 つ が図 4 右の「Drug Interactions Facts, David S., Facts \& Comparisons，ルーズリーフ差し替え式 である。臨床的評価, 対応, 機序が詳しく文献も 豊富で, その㥵互作用の重要度が 5 段階の数字 （重用なものほど数字は小さい）で表現されてお りわかりやすい。差し替え式なので常に新しい情 報を得ることができる。これらの情報をみるとジ ソピラミドとリファンピシンの相互作用は明確で あり，併用によってジソピラミドの代謝が進み, ジソピラミドの効果減弱が予測されることははっ きりしているようである。最近の研究でリファン
ピシンは肝臓の薬物代謝酵素をむっとも誘導しや すい薬として，併用に十分注意しなければならな い医薬品であることが知られている。

注：今年(1996) 6 月にジソピラミドの使用上の 注意がようやく改訂された。したがって, 最新の 添付文書には相互作用欄が追加され，リファンピ シンとの相互作用についても記載されている。し かし，PDRに図 2 のような情報が記載されたの は,なんと 1982 年。USP-DI に図 3 のような情 報が記載されたのは, 1984 年である。

その他の相互作用情報での有用な書籍としては, 以下のようなものがある。

医薬品が網羅的に紹介されている資料としては, 「医薬品相互作用, 仲川義人, 医薬ジャーナル社, 1994」がある。これは添付文書中の相互作用につ いての記載ばかりでなく, 相互作用の発現機序や 
症例報告の文献情報の要旨を一覧表で記載してい る。アメリカのものでは, 前述の Drug Interaction Factsに勝るとも劣らない資料「Drug Interactions \& Updates, Hansten P.D., Horn J.R., Lea \& Febiger, Applied Therapeutics, ルー ズリーフ差し替え式」がある。相互作用の機序, 処置, その臨床的意義はもち万ん記載されており, 文献あ豊富である。相互作用の評価は，3段階で 表現されている。

相互作用の最新の研究成果をまとめたものとし ては, 雑誌月刊薬事の増刊号で「薬物間相互作用 之医薬品の適正使用, 伊賀立二監修, 薬業時報社, 1996」がある。また, 具体的な相互作用の対処に ついて解説した「臨床医のための薬の相互作用と そのマネジメントーなぜ起こる, どう防ぐー，伊 賀立二監修, 南山堂, 1996」あ新しい書籍である。

薬と薬の相互作用ばかりでなく, 飲み物, 食べ 物との相互作用む重要である。この種の書籍とし ては, 「飲食物・嘴好品之医薬品の相互作用 改訂 2 版, 薬業時報社, 1993」がある。厚生省治療共 同研究班が行った文献調查を基に，430 件のデー 夕を薬効・食品・嗾好品別にまとめたもので, 飲 食物・啫好品, 医薬品名から検索できる。

薬の検查值への影響む相互作用である。この種 の書籍として新しいあのでは,「臨床検查値と薬 凨, 村井哲夫他, 南山堂, 1996」がある。アメリ カのむのでは, 少し古くなったが,「Effects of Drugs on Clinical Laboratory Tests 3rd ed., Young D.S., AACC Press, 1990」があり, 薬が 検查値に与える影響について内因的および外因的 (分析法)にわけて文献を紹介している。

\section{2. 副作用情報に関する書籍}

相互作用情報と並んで重要な位置を占めるのが 副作用情報である。副作用情報の情報源としては, 相互作用で解説した医薬品集がまず挙げられる。 ここでは, 副作用の専門書籍を紹介したい。
副作用情報においては，厚生省から隔月に出さ れる「医楽品副作用情報」が基本情報といえるが， この内容の解説書が出版されている。「Annual Report 医薬品の副作用 1990-1994, 伊藤宗元他 編，中外医学社」である。中央薬事審議会副作用 調查会之厚生省薬務局安全課の協力で副作用調查 会のメンバーが執筆している。総論, 副作用と薬 の使い方, 新医薬品等の副作用のまとめや発現頻 度, 医薬品副作用モニター報告の概要などが記載 され, 索引は医薬品名の和名, 英名, 副作用名加 ら検索できる。副作用之薬の使い方では，その年 の医薬品副作用情報に揭載された副作用について, 症例の紹介から臨床症状, 副作用の発現機序, 使 用上の注意点之安全対策, 文献等が詳しく解説さ れている。しかし，1995 年以降発行されておら ず，今後む発行される予定がないとのことで残念 である。

ここ数年, 医学書全般に症例や症状からの視点 で書かれた書籍が多くなってきている。副作用に おいても副作用症状から医薬品をみるという視点 で書かれたあのが新鮮で非常に有用である。その 老舖というべき書籍が,「症状からみた薬の副作 用, 名尾良憲, 中外医学社, 1986」である。薬の 副作用を副作用症状からみて解説してあり, 目次 は副作用の症状別になっている。索引は薬品名と 副作用名から検索できる。各副作用症状について の総論的な解説のあ之, 各副作用についての日本 および海外の論文を, 写真や薬歴, 図, 表をふん だんに使いながら紹介している。最近の書籍では, 「薬の副作用チェックマニュアル, 高橋隆一編集, 中外医学社，1994」がある。索引はあまり充実し ていないが，副作用の総説と症例が一体となった 書籍である。また,「この薬のこの副作用, 松田 重三編集，医歯薬出版，1996」は，現在多用され ている薬の覚えておくべき副作用をまとめたもの で, 薬剤の一般名や商品名, 副作用の症状から検 索できる。原因薬の説明, 副作用とその出現機序, 


\begin{tabular}{|c|c|c|c|c|c|c|c|c|c|c|c|}
\hline & 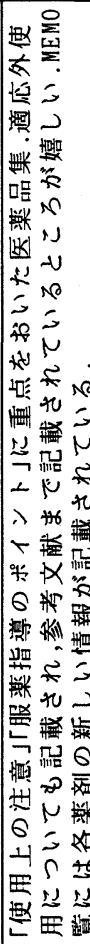 & 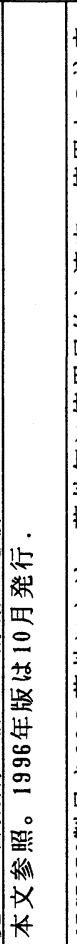 & 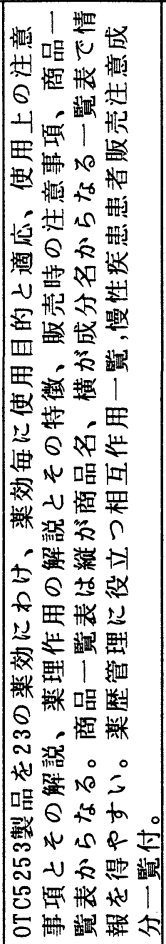 & 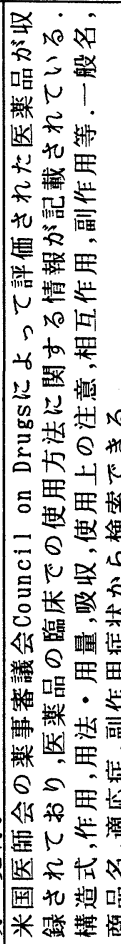 & 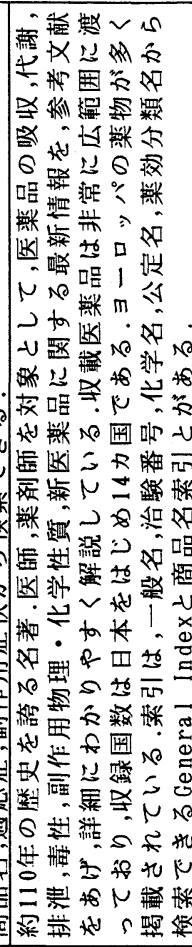 & & 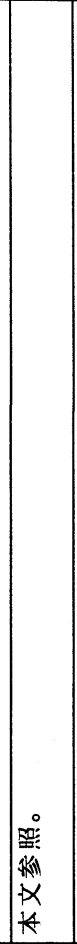 & 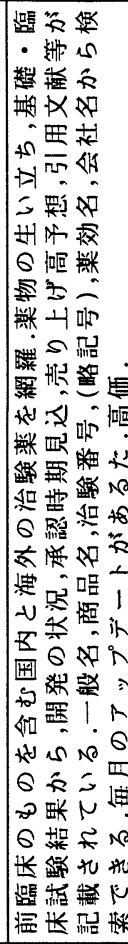 & 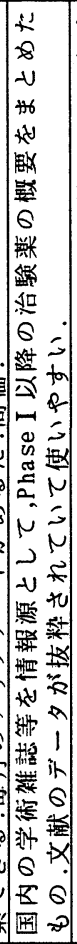 & 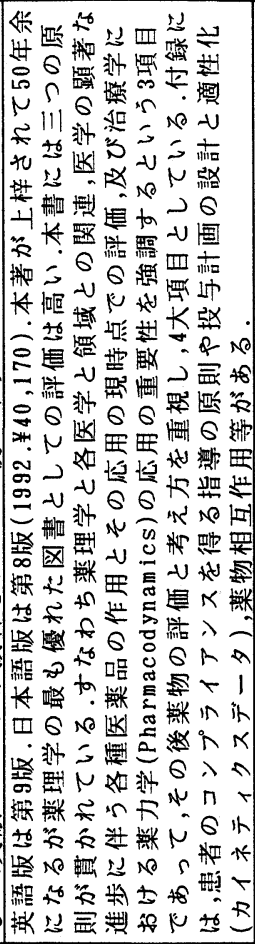 & 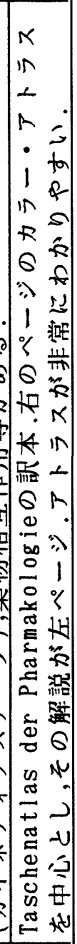 \\
\hline & & $\begin{array}{l}\stackrel{\circ}{\circ} \\
\frac{\Xi}{2}\end{array}$ & 咅 & $\begin{array}{l}\text { ¿े } \\
\stackrel{े}{\text { ลे }}\end{array}$ & 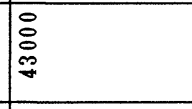 & $\begin{array}{l} \\
\vdots \\
\end{array}$ & $\mid \begin{array}{l}0 \\
0 \\
0 \\
i 0 \\
10\end{array}$ & 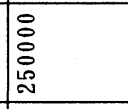 & 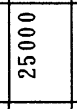 & $\stackrel{\circ}{\Xi}$ & $\frac{\infty}{\infty}$ \\
\hline & $\ddot{\infty}$ & 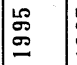 & $\begin{array}{l}\text { ஜ } \\
\text { g }\end{array}$ & $\begin{array}{l}\stackrel{L}{\circ} \\
\text { g }\end{array}$ & $\begin{array}{l}\mathscr{\infty} \\
\text { 足 }\end{array}$ & $\begin{array}{l}\infty \\
\sigma \\
\sigma\end{array}$ & $\begin{array}{l}\mathscr{\infty} \\
\Xi\end{array}$ & 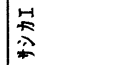 & $\begin{array}{l}\infty \\
\text { 邑 }\end{array}$ & $\begin{array}{l}\mathscr{0} \\
\text { 足 }\end{array}$ & $\begin{array}{l}\boldsymbol{I} \\
\text { హ} \\
\end{array}$ \\
\hline & 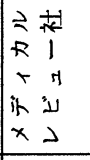 & 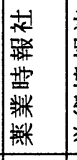 & 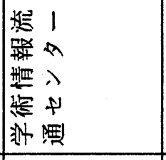 & 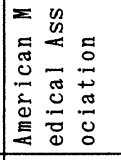 & 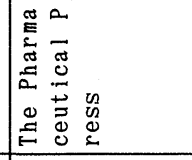 & 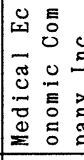 & 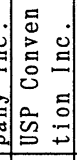 & 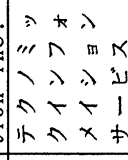 & $\mid \begin{array}{l}x \\
n \\
n\end{array}$ & 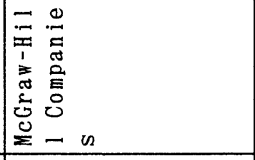 & 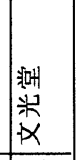 \\
\hline & 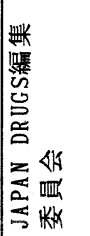 & 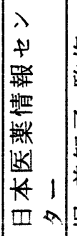 & 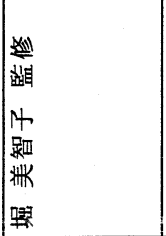 & & 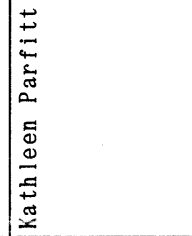 & & & & & & 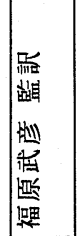 \\
\hline & 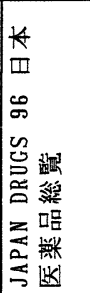 & 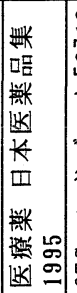 & 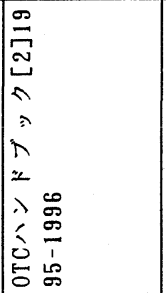 & 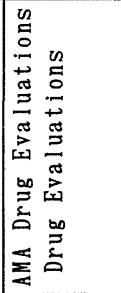 & 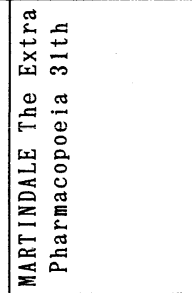 & 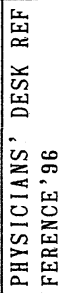 & 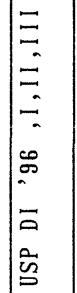 & 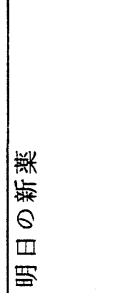 & 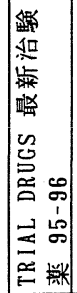 & 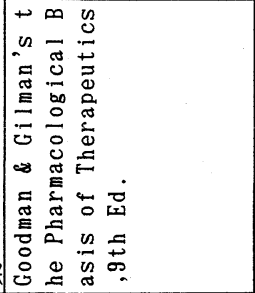 & 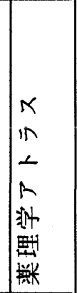 \\
\hline \multicolumn{3}{|c|}{ 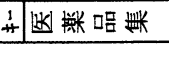 } & 国 太 & 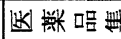 & K 曹々 & & & 垈的铁 & & 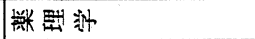 & \\
\hline
\end{tabular}




\begin{tabular}{|c|c|c|c|c|c|c|c|c|c|c|c|c|c|c|c|c|c|}
\hline 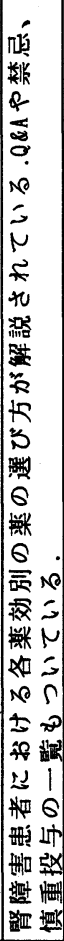 & 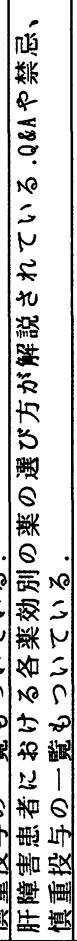 & 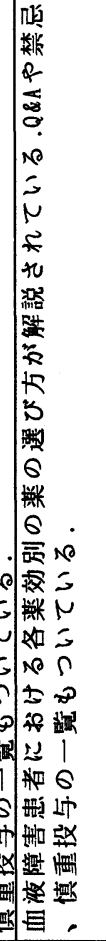 & 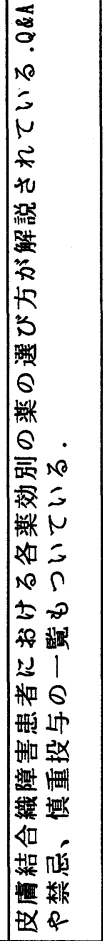 & 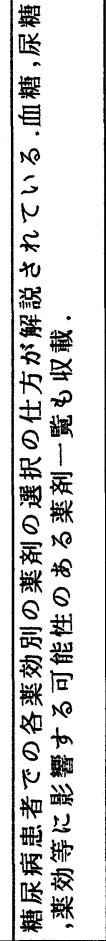 & 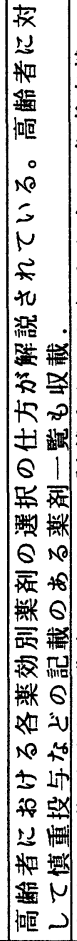 & 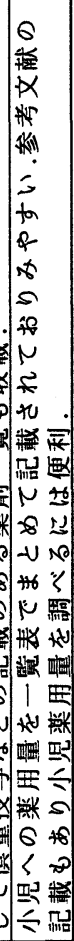 & 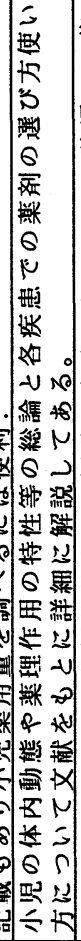 & 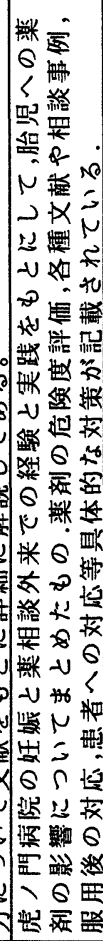 & 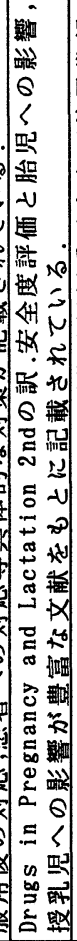 & 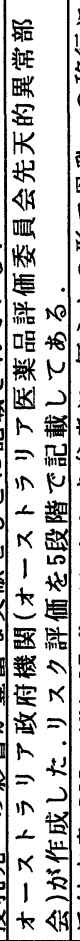 & 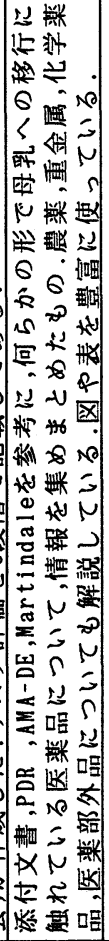 & 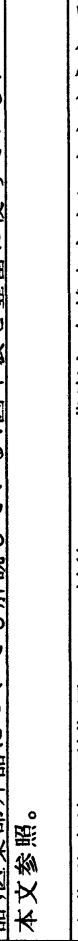 & 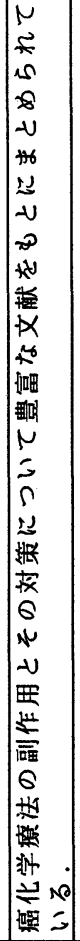 & 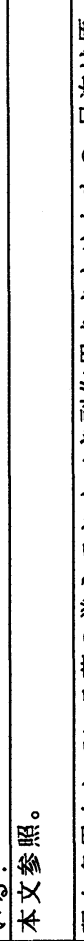 & 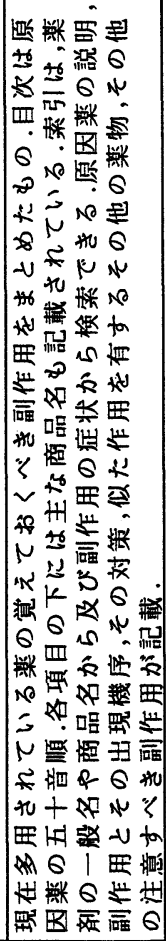 & 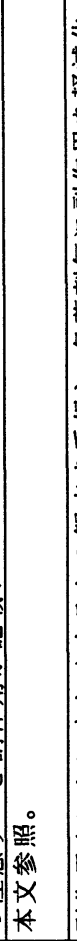 & 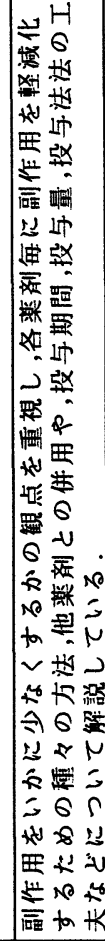 \\
\hline 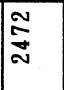 & 总 & 总 & 总 & 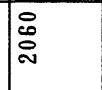 & $\begin{array}{l}0 \\
0 \\
\text { 足 }\end{array}$ & 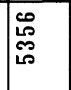 & 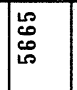 & 唐 & 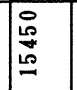 & $\bar{\Xi}$ & 足 & \begin{tabular}{|l|}
$* *$ \\
$*$ \\
$*$
\end{tabular} & ○े & 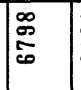 & $\frac{\infty}{6}$ & $\begin{array}{l}8 \\
8 \\
\infty \\
\infty\end{array}$ & 递 \\
\hline $\begin{array}{l}\infty \\
\infty \\
0 \\
-\end{array}$ & $\begin{array}{l}\infty \\
\infty \\
0 \\
\end{array}$ & 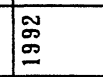 & 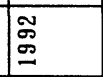 & $\begin{array}{l}\infty \\
\infty \\
0\end{array}$ & 욤 & 吕 & 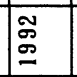 & 旅 & 跑 & 垔 & Бా & $*$ & 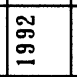 & $\sigma$ & 迥 & $\Xi$ & 10 \\
\hline $\begin{array}{l}\kappa \\
n \\
\prime \prime\end{array}$ & $\begin{array}{c}\kappa \\
n \\
n \prime \prime\end{array}$ & $\mid \begin{array}{l}\kappa \\
n \\
\prime \prime \prime\end{array}$ & $\begin{array}{c}r \\
n \\
\prime \prime \prime\end{array}$ & $\begin{array}{c}r \\
n \\
\text { n' }\end{array}$ & $\begin{array}{l}\kappa \\
n \\
\prime \prime \prime\end{array}$ & 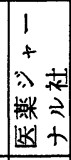 & 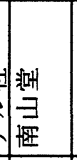 & 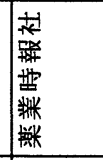 & 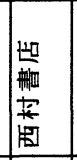 & 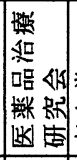 & 测 & 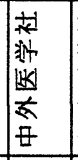 & 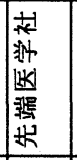 & 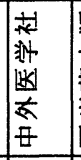 & 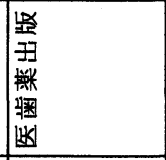 & \begin{tabular}{|l|}
$\underline{1}$ \\
$\vdots$ \\
$\mathbf{z}$ \\
$\mathbf{Z}$ \\
\end{tabular} & 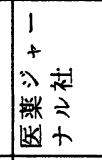 \\
\hline 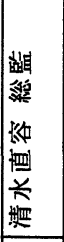 & 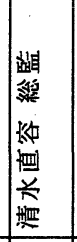 & 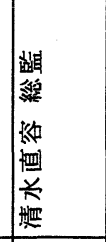 & 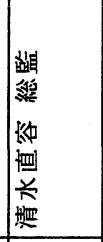 & 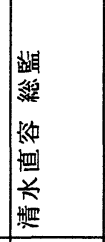 & 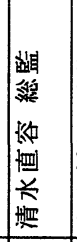 & 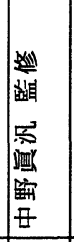 & 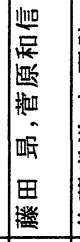 & 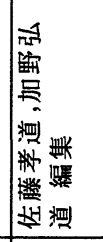 & 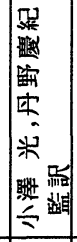 & 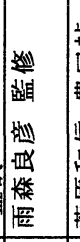 & 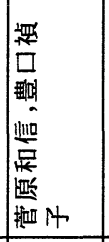 & 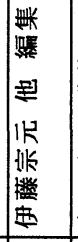 & 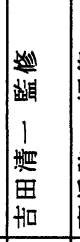 & $\mid$ & 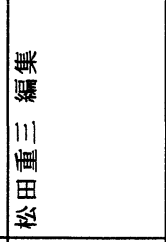 & 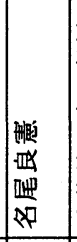 & 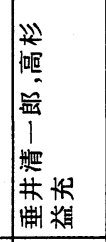 \\
\hline 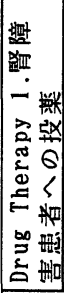 & 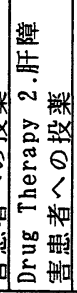 & 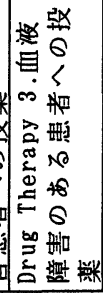 & 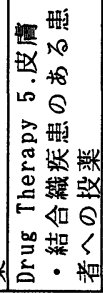 & 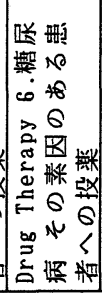 & 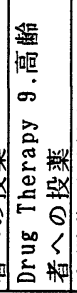 & 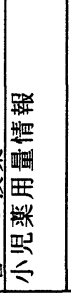 & 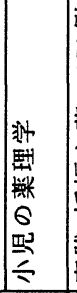 & 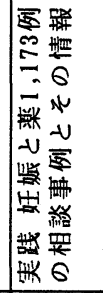 & 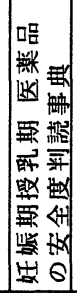 & 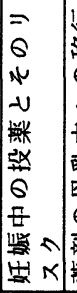 & 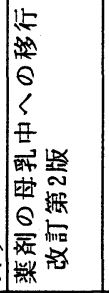 & 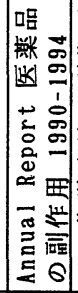 & 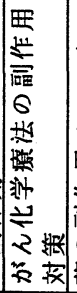 & 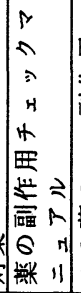 & 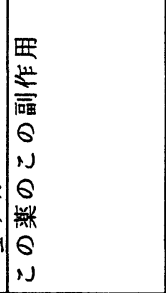 & 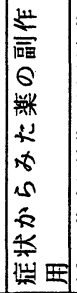 & 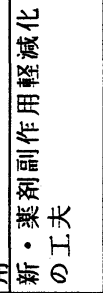 \\
\hline 亚 & E & 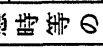 & 撒窟 & 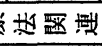 & & & & 幽紫 & & & & & & & & & \\
\hline
\end{tabular}




\begin{tabular}{|c|c|c|c|c|c|c|c|c|c|c|c|c|}
\hline 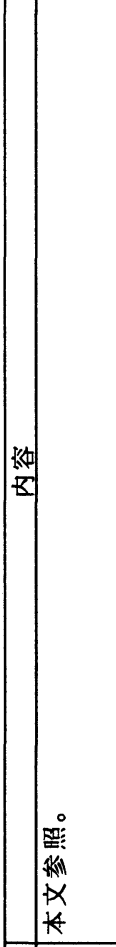 & 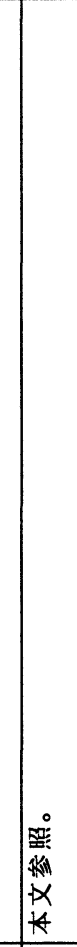 & 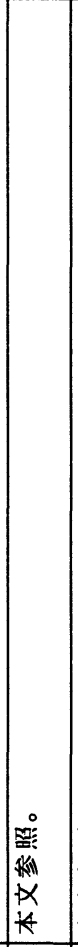 & 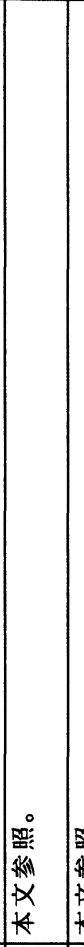 & 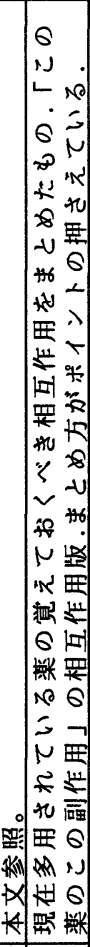 & & 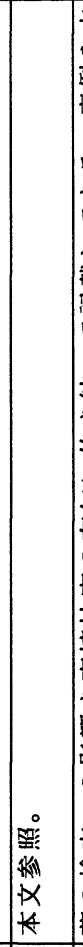 & 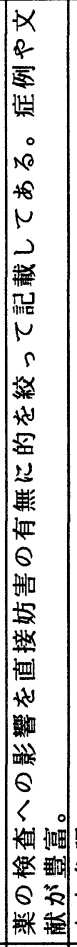 & 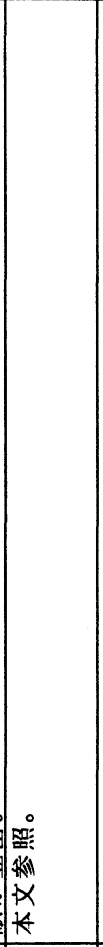 & 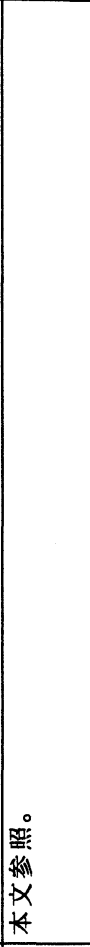 & 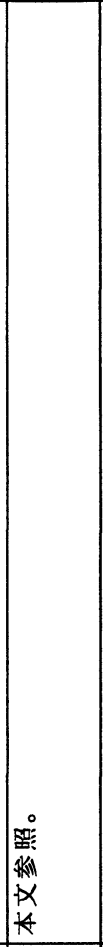 & 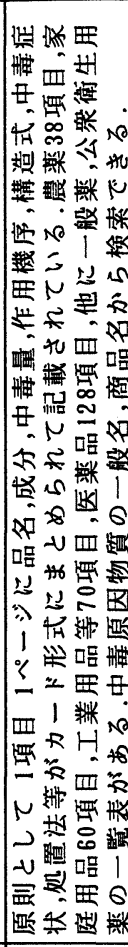 & 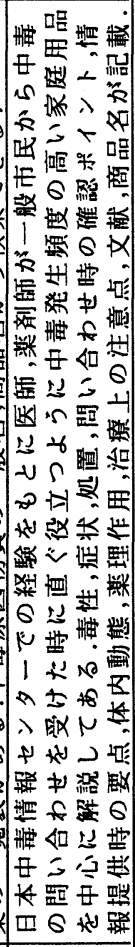 \\
\hline 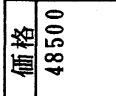 & 送 & 怘 & 音 & 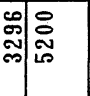 & 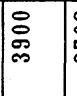 & $\mid \begin{array}{l}\mid \infty \\
0 \\
\infty\end{array}$ & \begin{tabular}{|l|} 
\\
\end{tabular} & 응 & 离 & 응 & $\begin{array}{l}\text { O } \\
\text { Lै } \\
\infty \\
0\end{array}$ & $\frac{8}{8}$ \\
\hline 翟告 & 芦 & 号 & \begin{tabular}{|l|} 
\\
号 \\
\end{tabular} & 句哥 & \begin{tabular}{|l|}
$\infty$ \\
\\
\end{tabular} & \begin{tabular}{|l|}
$\mathscr{\Omega}$ \\
\end{tabular} & \begin{tabular}{|l|}
$\infty$ \\
0 \\
\\
\end{tabular} & $\overrightarrow{5}$ & 勾 & 通 & $\begin{array}{l}\mathscr{8} \\
\mathscr{9} \\
\end{array}$ & 䒠 \\
\hline 教学 & 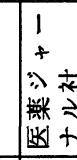 & 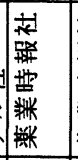 & 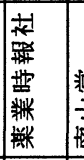 & 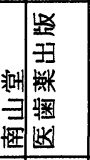 & 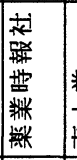 & $\mid$ & 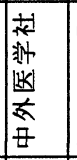 & 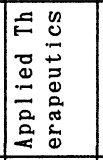 & 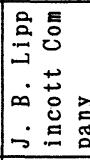 & 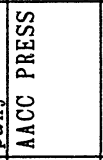 & 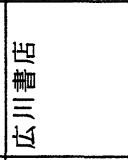 & 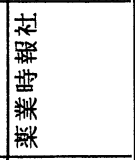 \\
\hline 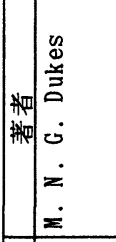 & 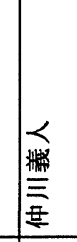 & 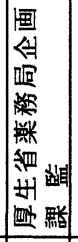 & & 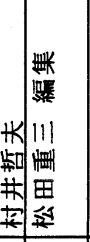 & 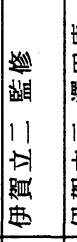 & 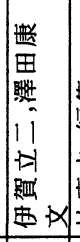 & 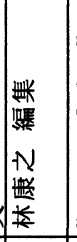 & 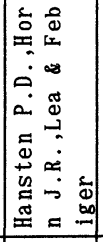 & 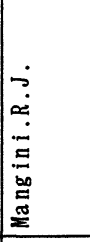 & $\begin{array}{l}\ddot{2} \\
0 \\
0 \\
\infty \\
\vdots \\
0 \\
0\end{array}$ & 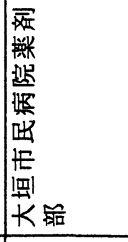 & 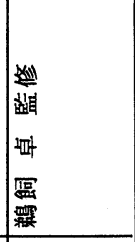 \\
\hline 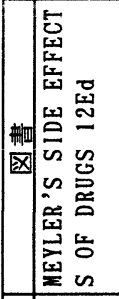 & 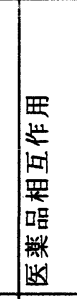 & 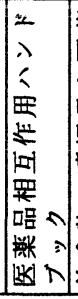 & 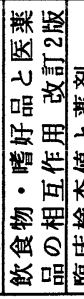 & 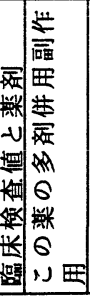 & 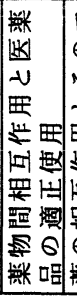 & 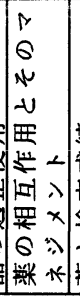 & 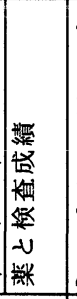 & 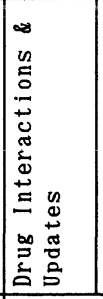 & 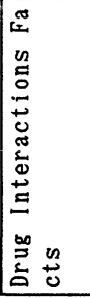 & 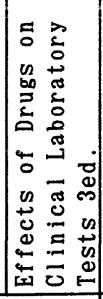 & 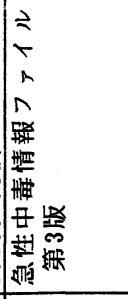 & 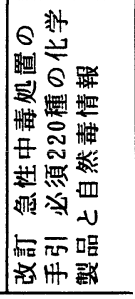 \\
\hline \begin{tabular}{|l|l|}
+ & 而 \\
\end{tabular} & 因 & 1 㘳田 & 四 & & & & & 要时 & 国 㫣 & & 世楼 & \\
\hline
\end{tabular}




\begin{tabular}{|c|c|c|c|c|c|c|c|c|c|c|c|c|c|}
\hline 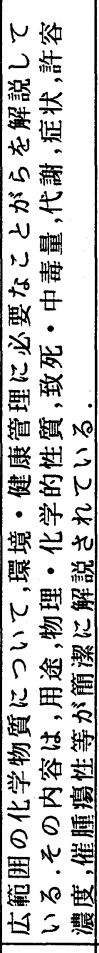 & 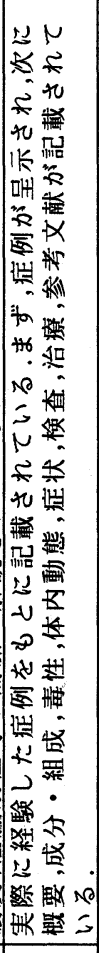 & 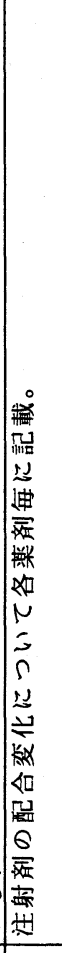 & 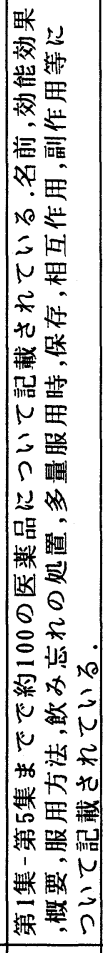 & 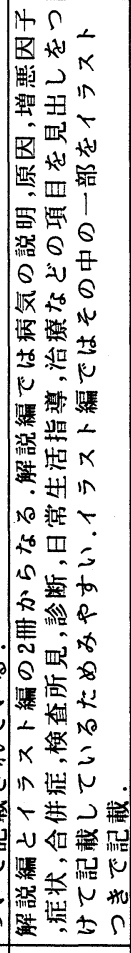 & 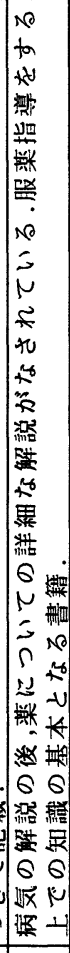 & 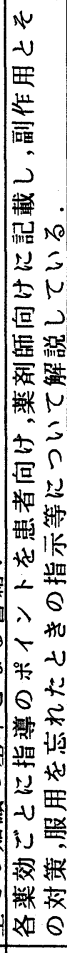 & 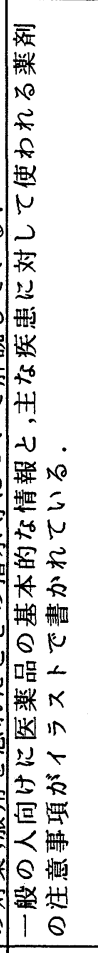 & 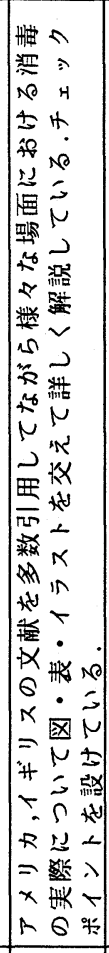 & 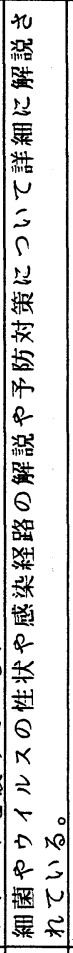 & 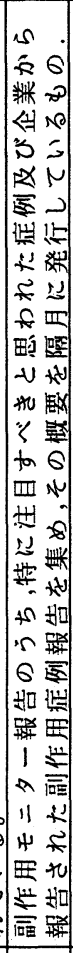 & 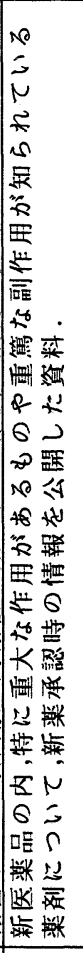 & 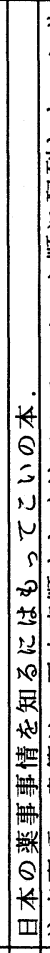 & 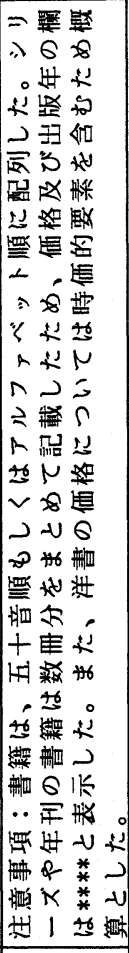 \\
\hline $\begin{array}{l}0 \\
8 \\
8 \\
0 \\
0\end{array}$ & 怘 & 店 & $\begin{array}{l}\stackrel{*}{*} \\
\stackrel{*}{*} \\
*\end{array}$ & 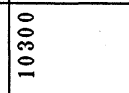 & $\begin{array}{l}0 \\
0 \\
0 \\
\text { ¿ }\end{array}$ & 章 & $\begin{array}{l}0 \\
0 \\
0 \\
0\end{array}$ & 号 & 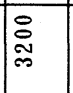 & 0 & $\begin{array}{l}* \\
* \\
* \\
*\end{array}$ & क이 & \\
\hline$\infty$ & g & : & & 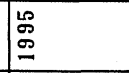 & Бా & 曲 & 占 & ฮี & 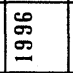 & & \begin{tabular}{|l}
$*$ \\
$*$ \\
$*$ \\
$*$ \\
$*$
\end{tabular} & $\begin{array}{l}\mathscr{\sigma} \\
\sigma\end{array}$ & \\
\hline 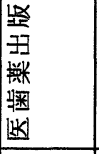 & 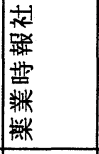 & 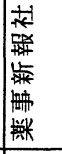 & 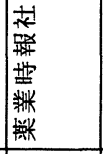 & $\begin{array}{l}\text { 测 } \\
\text { 叫 }\end{array}$ & $\begin{array}{l}\text { 政 } \\
\text { 橧 }\end{array}$ & 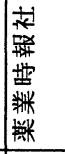 & 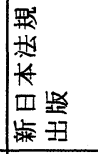 & 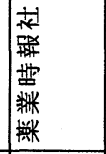 & ti & 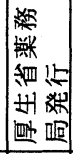 & 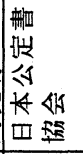 & 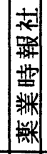 & \\
\hline 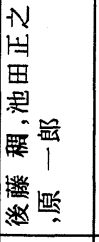 & 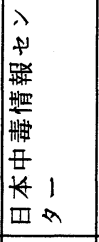 & 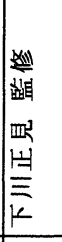 & 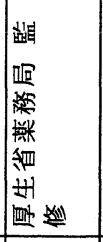 & 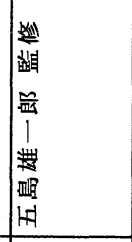 & 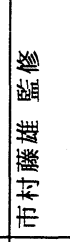 & 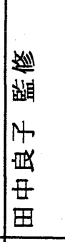 & 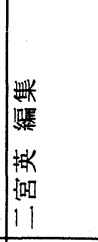 & 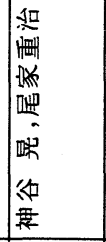 & 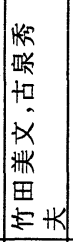 & & 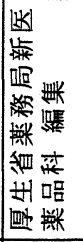 & & \\
\hline 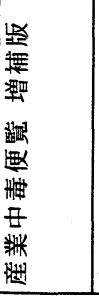 & 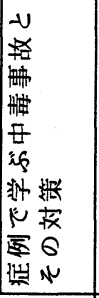 & 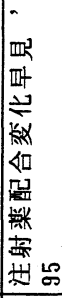 & 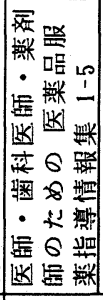 & 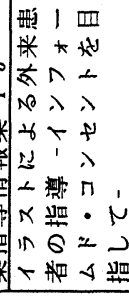 & 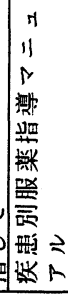 & 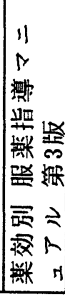 & 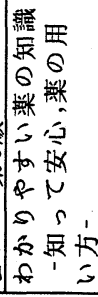 & 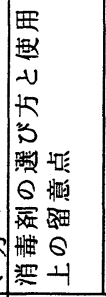 & 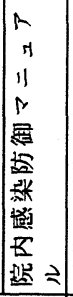 & 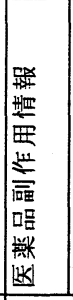 & 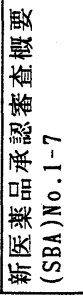 & 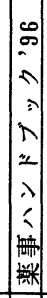 & \\
\hline \multicolumn{2}{|l|}{ \#糔 } & 藏 & & & & & & 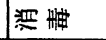 & 增秋 & \multicolumn{2}{|c|}{ 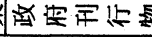 } & 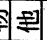 & \\
\hline
\end{tabular}


対策，似た作用を有するその他の薬物，その他の 注意すべき副作用が解説されている。海外のもの で評価の高い資料が「Meyler's Side Effects of Drugs, Dukes M.N.G., Elsevier, 1992」である。 オランダ薬物評価委員会副会長 M.N.G.デューク スの編集になる医薬品の有害作用および相互作用 に関連する研究報告を総括した専門書である。こ れはだいたい 5 年ごとに発行され，その間は， 「Side Effects of Drugs Annual」として毎年発行 されている。この領域での最近の進歩を多数の文 献を添えて厳密に検討したものが収載されている。

\section{3. その他の領域の書籍}

表 1 に各領域の書籍のうち, 特に有用なむのを 挙げた。

疾患や治療に関する書籍および臨床検査に関す る書籍等は医学図書館においては充実していると 考え, 割愛した。また, 個々の医薬品の専門書籍 についても割愛している。

\section{III. 終わりに}

医薬品情報において特に有用な書籍を紹介した。 1997 年 4 月 1 日から, 薬剤師法の改正が行わ
れる。この改正により, 薬剤師が医薬品を調㓮す るときは，薬の適正な使用のための「情報」を一 緒に患者に提供することが義務化された。薬剤師 がチーム医療の一員として, その職能を発揮する ことが社会的な要請となってきたのである。この ような社会情勢の中で，医薬品情報の重要性はま すます高まってくると考えられる。今までは，医 学図書館を薬剤師が利用する機会は少なかったの が現実ではないだろうか。しかし，今までのよう に薬局にある添付文書だけを医薬品情報源として いては, チーム医療の一員としてその職能を発揮 することはできない。医学図書館は臨床情報の宝 庫である。しかし, 医薬品情報に関する資料は二ズが少なかったかもしれない。今後は薬剤師が医 学図書館を利用する機会む多くなってくると思わ れる。ぜひ，この分野の資料の充実も打願いした $\omega_{0}$

メディアの進歩やインターネットの急速な普及 によって, 書籍や雑誌, 二次資料の出版形態む変 化しつつある。今後は, これらの動向も見据えな がら, 新しい医薬品情報の展開を模索していきた いと考えている。 